\title{
PENGARUH PERPUTARAN MODAL KERJA DAN PERPUTARAN KAS TERHADAP PROFITABILITAS PERUSAHAAN
}

\section{(Studi kasus pada perusahaan properti dan perusahaan manufaktur yang terdaftar pada BEI tahun 2010-2012)}

\author{
oleh \\ Danifana Maeka Fayani, \\ Fatmasari Sukesti \\ Ayu Noviani Hanum \\ Email : danifanamaeka@gmail.com \\ Fakultas Ekonomi Universitas Muhammadiyah Semarang
}

\begin{abstract}
ABSTRAK
Penelitian ini bertujuan untuk mengetahui pengaruh perputaran modal kerja dan perputarankas terhadap profitabilitas secara parsial dan simultan, dan untuk mengetahui apakah terdapat perbedaan antara perputaran modal kerja, perputaran kas terhadap profitabilitas pada perusahaan properti dan perusahaan manufaktur.

Metode penelitian yang digunakan adalah metode deskriptif kuantitatif dengan metode analisis regresi linier berganda. Sampel yang digunakan berjumlah 46 perusahaan, 11 perusahaan properti dan 35 perusahaan manufaktur. Hasil penelitian menunjukkan variabelperputaran modal kerja dan variabel perputaran kas berpengaruh terhadap profitabilitas (ROA) dengan R square sebesar 0,431. Dengan uji beda menunjukkan perputaran modal kerja 20.144920 dan perputaran kas senilai 33.717649 pada perusahaan manufaktur, perputaran modal kerja 6.542924 dan perputaran kas 10.487194 pada perusahaan properti, sehingga perusahaan manufaktur lebih unggul di bandingkan dengan perusahaan properti.
\end{abstract}

Kata kunci: Perputaran modal kerja, perputaran kas, profitabilitas (Return On Asset).

\section{ABSTRACT}

This study aims to determine the effect of rotation of working capital and cash turnover on profitability partially and simultaneously, and to determine whether there is a difference working capital turnover and cash turnover on profitability between property companies and manufacturing companies.

The method used descriptive quantitative method with multiple linear regression analysis. The sample was 46 companies, 11 property companies and 35 manufacturing companies. The results showed a variable rotation of working capital and cash turnover variable effect on profitability (ROA) with $R$ square of 0,431. With different test showed that working capital turnover valued 20.144.920 and cash turnover valued 33.717649 at manufacturing companies, working capital turnover valued 6.542924 and cash turnover valued 10.487194 in the company's property, so that manufacturing companies are superior in comparison with the propertycompany.

Keywords: working capital turnover, cash turnover, profitability (return on assets). 


\section{PENDAHULUAN}

Pentingnya perputaran modal kerja dan perputaran kas terhadap profitabilitas Return On Asset yang digunakan oleh perusahaan sebagai tolak ukur berhasilan suatu perusahaan dalam mengelola suatu sumber dana yang dimilikinya agar dapat digunakan secara efektif dalam upaya meningkatkan profitabilitas Return On Asset perusahaan. Hasan dalamdeni(2014) Keberhasilan suatu perusahaan akan lebih mudah dicapai dengan adanya perencanaan bisnis properti baik residensial maupun komersial yang menunjukan perkembangan cukup pesat di Indonesia, terbukti dengan semakin maraknya pembangunan perumahan, pusat bisnis dan supermall dalam tahuntahun terakhir yang semakin naik.

Sriwahyuni

Perkembangan sektor properti ini diikuti dengan tingginya permintaan akan kebutuhan dalam perkembangan perekonomian saat ini, perusahaan properti dan perusahaan manufaktur bekerjasama dalam dunia industri. Perusahaan manufaktur perlu melakukan investasi untuk meningkatkan modal usaha perusahaan. Untuk melakukan investasi diperlukan berbagai macam informasi tentang emiten, baik informasi lain yang relevan. Sehingga membuat para emiten property membutuhkan dana dari eksternal.

Pendanaan dari sumber eksternal dapat diperoleh dari pasar modal, investor menginvestasikan modalnya di industri properti karena harga tanah dan harga bahan produksi yang cenderung naik. Kebutuhan akan pasar modal akan berdampak pada perusahaan yaitu kemampuan untuk meningkatkan industri dengan meningkatkan profitabilitas perusahaan properti dan manufaktur dapat dipengaruhi oleh banyak faktor keuangan yang dapat diukur dengan menggunakan rasio keuangan diantaranya adalah Net Profit Margin, Gross Profit Margin, Return On Investment, Return On Asset, Return On Equity.

Kemampuan perusahaan untuk menghasilkan laba dapat menarik para investor untuk menanamkan dananya guna memperluas usahanya, sebaliknya tingkat profitabilitas yang rendah akan menyebabkan para investor menarik dananya. Dengan demikian bagi investor jangka panjang akan sangat berkepentingan dengan analisa profitabilitas ini. Sedangkan bagi perusahaan itu sendiri profitabilitas 
dapat digunakan sebagai evaluasi atas efektivitas pengelolaan badan usaha tersebut.

\section{Tinjauan Pustaka}

Menurut Weston dan Brigham(1999) modal kerja adalah Total nilai investasi di perusahaan dalam harta jangka pendek (Gross Working Capitalseperti kas, piutang dagang, pembayaran yang dilakukan di muka atau total nilai investasi perusahaan dalam aktiva lancar dikurangi kewajiban lancar yang di gunakan untuk membiayai aktiva lancar tersebut (Net Working Capital).Kasmir (2013) Sedangkan pengertian perputaran kas merupakan perbandingan antara penjualan dengan jumlah kas rata-rata. Semakin tinggi perputaran kas ini akan semakin baik. Karena ini berarti semakin tinggi efisiensi penggunaan kasnya dan keuntungan yang diperoleh akan semakin besar pula. Menurut Syafri (1999) profitabilitas suatu perusahaan adalah kemampuan perusahaan mendapatkan laba melalui semua kemampuan dan sumber yang ada seperti kegiatan penjualan, kas, modal, jumlah karyawan, jumlah cabang dan sebagainya.

\section{Kerangka pemikiran dan Hipotesis}

perputaran modal kerja dan hubungan tingkat perputaran modal kerja dengan profitabilitas.
Riyanto (2008) Perputaran modal kerja merupakan alat untuk mengukur keefektifan pendayagunaan modal kerja untuk melaksanakan kegiatan perusahaan dan menunjukkan banyaknya penjualan yang dapat diperoleh perusahaan untuk tiap rupiah modal kerja. Hasil peneletian sebelumnya Azlina (2009) menyatakan perputaran modal kerja berpengaruh positif dan signifikan terhadap profitabilitas (ROA).

Berdasarkan Uraian diatas maka dapat diambil hipotesis sebagai berikut :

$\mathrm{H} 1$ : Perputaran modal kerja $\left(\mathrm{X}_{1}\right)$ berpengaruh positif terhadap profitabilitas Return On Asset perusahaan properti dan perusahaan manufakturdi BEI.

Perputaran kas dan pengaruh tingkat perputaran kas terhadap rrofitabilitas (ROA).

Mulyono (2000) perputaran kas menunjukkan tinggi rendahnya kas yang berputar di bank setiap periodenya semakin tinggi perputaran kas berarti makin baik dan sebaliknya makin rendah perputaran kas berarti makin buruk, karena tingkat perputaran kas menunjukkan tinggi rendahnya efisiensi penggunaan kas.Hasil peneletian sebelumnya Pratiwi (2012) menyatakan perputaran kas berpengaruh positif dan signifikan terhadap profitabilitas (ROA). 
Berdasarkan Uraian diatas maka dapat diambil hipotesis sebagai berikut :

$\mathrm{H} 2$ : Perputaran kas $\left(\mathrm{X}_{2}\right)$ berpengaruh positif terhadap profitabilitas Return On Assetperusahaan properti dan perusahaan manufakturdi BEI.

Rasio profitabilitasReturn On Asset (ROA)

Menurut Hanafi (2008) "Return On Asset adalah rasio yang mengukur kemampuan perusahaan untuk menghasilkan laba dengan menggunakan total asset (kekayaan) yang dimiliki perusahaan setelah disesuaikan dengan biaya-biaya untuk menandai asset tersebut.

Berdasarkan Uraian diatas maka dapat diambil hipotesis sebagai berikut :

H3 : Perputaran modal kerja dan perputaran kas secara simultan berpengaruh terhadap profitabilitas Return On Asset (Y)perusahaan properti dan perusahaan manufakturdi Bursa Efek Indonesia.

H4 :Terdapat perbedaan antara perputaran modal kerja, perputaran kas dan profitabilitas pada perusaah properti dan perusahaan manufaktur.

\section{METODE PENELITIAN}

Populasi dan Sampel
Penelitian ini adalah perusahaan properti dan manufakturyang terdaftar di Bursa Efek Indonesia pada tahun 20102012. Teknik pengambilan sampel dilakukan dengan metode Purposive Sampling, metode Purposive Sampling merupakan teknik penentuan sampel dengan pertimbangan tertentu yang sering di gunakan oleh peneliti dalam penelitian.Terdapat 11 Perusahaan Properti serta 35 perusahaan manufaktur yang terdaftar di Bursa Efek Indonesia 20102012 yang akan dijadikan sampel.

\section{Jenis dan sumber data}

Jenis dan sumber data yang digunakan dalam penelitian ini yaitu data sekunder yang diperoleh dari Indonesian Capital Market Directory (ICMD)dan website www.idx.co.idberupa laporan keuangan setiap perusahaan dari tahun 2010-2012 dan tahun2009-2013.

\section{Teknik pengumpulan data}

Teknik pengumpulan data dalam penelitian ini dilakukan denganPurposive Sampling. Sugiyono(2006)Purposive Sampling merupakan teknik penentuan sampel dengan pertimbangan tertentu yang sering di gunakan oleh peneliti dalam penelitian yang dipublikasikan oleh Indonesian Capital Market Directorydan www.idx.co.idtentang perusahaan yang terdaftar di Bursa Efek Indonesia selamapengamatanperiode 2010-2012.

Teknik Analisis Data 
Penelitian ini bertujuan untuk mengetahui bagaimana pengaruh antara perputaran modal kerja dan perputaran kas terhadap profitabilitas (ROA). Tekni analisis yaitu regresi berganda.

Model Persamaan Regresi Berganda

$$
\mathrm{Y}=\mathrm{a}+\mathrm{b}_{1} \mathrm{X}_{1}+\mathrm{b}_{2} \mathrm{X}_{2}+\mathrm{e}
$$

keterangan :

$$
\begin{aligned}
\mathrm{Y} & =\text { Return On Asset } \\
\mathrm{a} \quad= & \text { Konstanta, besar } \\
& \text { nilai Y jika X=0 } \\
\text { b1-b3 } & \text { Koefisien arah } \\
& \text { regresi, yang } \\
& \text { menyatakan } \\
& \text { perubahan nilai } \mathrm{Y} \\
& \text { apabila terjadi } \\
& \text { perubahan nilai } \mathrm{X} \\
= & \text { Perputaran modal } \\
\mathrm{X}_{1} \quad & \text { kerja } \\
\mathrm{X}_{2} \quad & \text { Perputaran kas } \\
\mathrm{E} \quad= & \text { Standard error }
\end{aligned}
$$

HASIL ANALISIS DATA DAN PEMBAHASAN

Gambaran Umum Obyek Penelitian
Obyek penelitian yang digunakan dalam penelitian ini adalah perusahaan manufaktur yang terdaftar di Bursa Efek Indonesia (BEI) periode 2010-2012. Perusahaan yang telah memenuhi kriteria yang ditetapkan dan dapat digunakan sebagai sampel dalam penelitian ini sejumlah 46 perusahaan di setiap periode penelitian yaitu 2010-2012. Dengan menggunakan metode penggabungan data (pooling) maka diperoleh data penelitian sebanyak 3 x $46=138$.

\section{Deskriptif Statistik Variabel Penelitian}

Berdasarkan hasil analisis deskripsi statistik, maka pada Tabel 4.2 hasilanalisisdeskripsistatistikselamapengam atan 3 tahunpadaperiode 2010 -2012.

Tabel 4.2

Hasil Analisis Deskriptif Data

\begin{tabular}{|l|r|r|r|c|c|}
\hline \multicolumn{1}{|c|}{ Varriabel bebas } & \multicolumn{1}{c|}{ N } & \multicolumn{1}{c|}{ Minimum } & \multicolumn{1}{c|}{ Maximum } & Mean & \multicolumn{1}{c|}{ Std. Deviasi } \\
\hline Perputaran Modal Kerja $\left(\mathrm{X}_{1}\right)$ & 138 & 1,2964 & 92,2961 & 16,89227 & 21,9204892 \\
\hline perputaran Kas $\left(\mathrm{X}_{2}\right)$ & 138 & 1,0328 & 138,2677 & 28,16254 & 26,8314739 \\
\hline ROA (Y) & 138 & 1,1032 & 85,5656 & 18,19315 & 21,8728086 \\
\hline
\end{tabular}

Sumber: Data Sekunder yang diolah, 2015

Dari Hasil kedua Tabel diatas, dapat dijelaskan bahwa jika standar deviasi lebih besar dari nilai mean-nya dikatakan memiliki sebaran yang besardan standar deviasi lebih kecil dari nilai mean-nyadikatakan memiliki sebaran yang kecil. 


\section{Pengujian Asumsi Klasik}

\section{Uji Heterokedastisitas}

Mudrajat Kuncoro (2004) Uji heterokedastisitas muncul apabila kesalahan atau residual dari model yang diamati tidak memiliki varians yang konstan dari satu observasi ke observasi lainnya. Artinya, setiap observasi mempunyai reliabilitas yang berbeda akibat perubahan dalam kondisi yang melatar belakangi tidak terangkum dalam spesifikasi model.

Data yang digunakan untuk uji heteroskedastisitas ini adalah data dari variabel independen setelah outlierdihilangkan. Hasil uji heteroskedastisitas dengan menggunakan grafik scatterplot di tunjukan pada Grafik 4.2 di bawah ini:

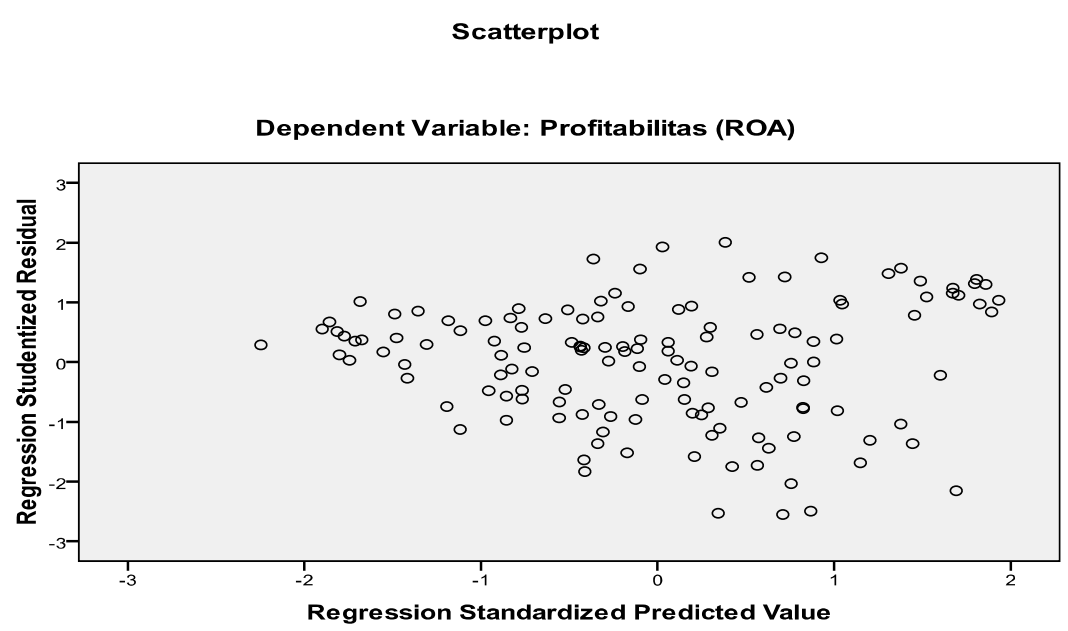

Berdasarkan scatterplot diatas dapat dilihat bahwa titik-titik menyebar secara merata diatas maupun dibawah angka nol serta tidak membentuk pola yang teratur.

\section{Uji Normalitas}

Uji Normalitas bertujuan untuk menguji apakah dalam model regresi variabel terikat dan variabel bebas keduanya mempunyai distribusi normal atau tidak. Cara yang bisa ditempuh untuk menguji kenormalan data adalah dengan menggunakan Grafik Normal P-P Plot dengan cara melihat penyebaran datanya. Jika pada grafik tersebut penyebaran datanya mengikuti pola garis lurus, maka datanya normal. Jika pada tabel test of normality dengan menggunakan Kolmogorov-Smimov nilai sig > 0.05, maka data berdistribusi normal. Adapun Uji Normalitas dalam penelitian ini adalah sebagai berikut: 


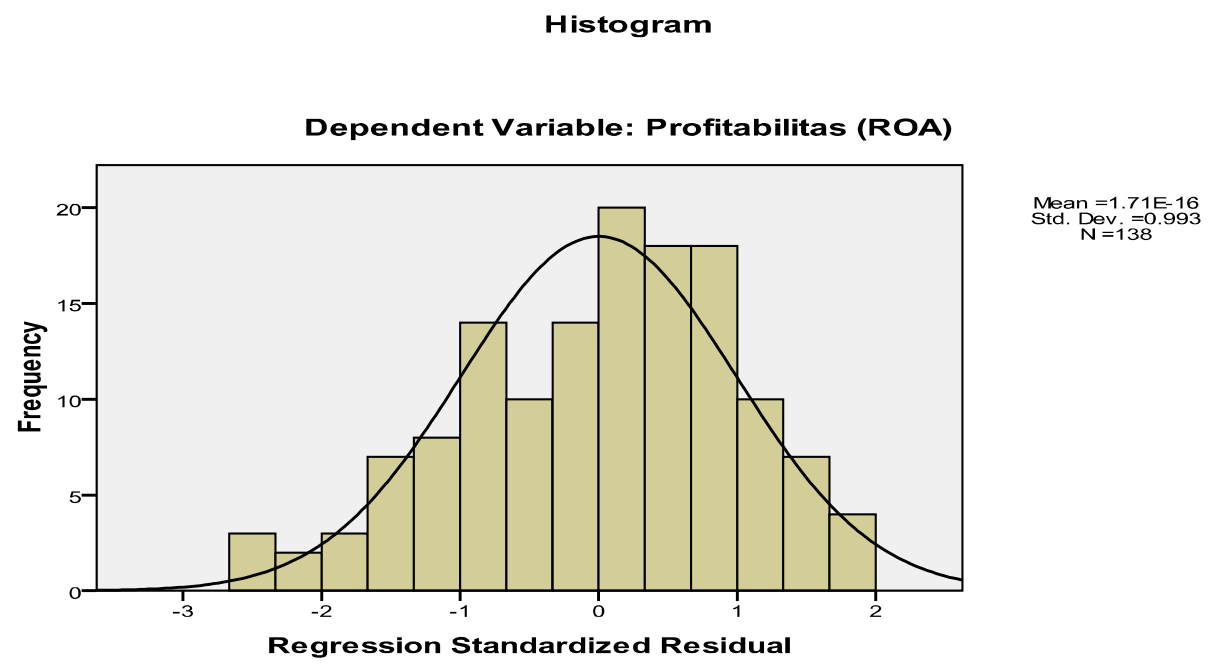

Tabel 4.5

Uji Normalitas Kolmogorov-Smirnov

\begin{tabular}{|l|r|}
\hline \multicolumn{1}{|c|}{ Uji Kolmogorov-Smirnov } & \multicolumn{2}{|c|}{$\begin{array}{c}\text { Unstandarized } \\
\text { Residual }\end{array}$} \\
\hline Nilai Kolmogorov-Smirnov & 1.033 \\
\hline Sig & 0,236 \\
\hline
\end{tabular}

Sumber: Data sekunder diolah, 2015

Berdasarkan Uji Normalitas Kolmogorov-Smirnov pada tabel diatas, menunjukkan tingkat signifikansi sebesar 0,236 atau lebih besar dari 0,05 pada tingkat kepercayaan 95\%. Dengan demikian, residual data berdistribusi normal dan model regresi telah memenuhi asumsi normalitas.

Hasil pengujian data normalitas juga didukung dengan grafik 4.3 normal plot dibawah ini :

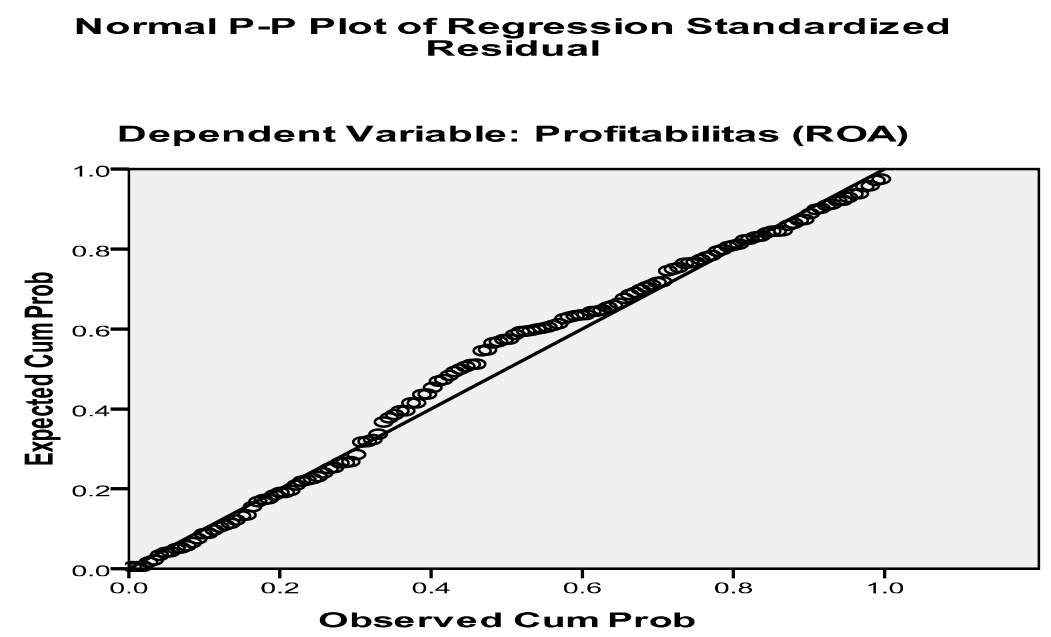




\section{Analisis Regresi Linier Berganda}

Tabel 4.6

Uji Regresi Linier Berganda

\begin{tabular}{|l|r|}
\hline \multicolumn{1}{|c|}{ Model 1 } & $\begin{array}{c}\text { Unstandardized Coefficients } \\
\text { (B) }\end{array}$ \\
\hline Konstanta & 2,661 \\
\hline Perputaran Modal Kerja $\left(\mathrm{X}_{1}\right)$ & 0,496 \\
\hline Perputaran Kas $\left(\mathrm{X}_{2}\right)$ & 0,254 \\
\hline
\end{tabular}

Sumber: Data sekunder diolah, 2015

Berdasarkan hasil analisis 0,496, PerputaranKas $\left(X_{2}\right)=0,254$, dan regresi berganda pada tabel di atas konstanta sebesar 2,661 sehingga diperoleh koefisien untuk variabel model persamaan regresi yang bebasPerputaran Modal Kerja $\left(\mathrm{X}_{1}\right)=$ diperoleh adalah:

$$
Y=2,661+0,496 X_{1}+0,254
$$

a. Nilai konstan ( Y ) sebesar 2,661 artinya jika perputaran modal kerja $\left(\mathrm{X}_{1}\right)$ dan variabel perputaran kas $\left(\mathrm{X}_{2}\right)$ nilainya adalah $0(\mathrm{nol})$, maka variabel Return On Asset (Y) akan berada pada angka 2,661 .

b. Koefisien regresi $\mathrm{X}_{1}$ (perputaran modal kerja) dari perhitungan linier berganda didapat nilai coefficients $\left(b_{1}\right)=0,496$, . Hal ini berarti setiap ada peningkatan perputaran modal kerja $\left(\mathrm{X}_{1}\right)$ sebesar $1 \%$ maka Return On Asset (Y) juga akan menurunsebesar 49,6\% dengan anggapan variabel perputaran kas $\left(\mathrm{X}_{2}\right)$ adalah konstan.

c. Koefisien regresi $\mathrm{X}_{2}$ (perputaran kas) dari perhitungan linier berganda didapat nilai coefficients $\left(b_{2}\right)=0,254$. Hal ini berarti setiap adapeningkatan perputaran kas $\left(\mathrm{X}_{2}\right)$ sebesar $1 \%$ maka Return On Asset (Y) akan meningkat,sebesar $25,4 \%$ dengan anggapan variabel perputaran modal kerja $\left(\mathrm{X}_{1}\right)$ adalah konstan.

\section{AnalisisKorelasi}

Menurut

Sugiyono(2000)Analisis korelasi yang digunakan dalam penelitian ini adalah korelasi ganda dengan alasan 
karena korelasi ganda merupakan angka yang menunjukkan arah dan kuatnya hubungan antara dua variabel secara bersama-sama atau lebih dengan variabel lain. Rumus korelasi adalah sebagai berikut:

$$
R y \cdot x_{1} \cdot x_{2}=\frac{r^{2} y x_{1}+r^{2} y x_{2}-2 r y x_{1} r y x_{2}}{1-r 2 X_{1} X_{2}}
$$

Dimana :

Ry. $\mathrm{x}_{\mathrm{X} 2}$ : Korelasi antara variabel $\mathrm{x}_{1}$ dan $\mathrm{x}_{2}$ secara bersama-sama dengan variabel y

$\operatorname{Ryx}_{1} \quad: \quad$ Korelasi product moment antara $\mathrm{x}_{1}$ dengan $\mathrm{y}$
$\operatorname{Ryx}_{2} \quad$ : Korelasi product moment antara $\mathrm{x}_{2}$ dengan $\mathrm{y}$

$\mathrm{Rx}_{1 \mathrm{X} 2} \quad$ : Korelasi product moment antara $\mathrm{x}_{1}$, dengan $\mathrm{x}_{2}$ dengan $\mathrm{y}$

Hasil dari analisis korelasi sebagai berikut:

NilaiKorelasi Antara Variabel $X_{1}$ dan $\mathrm{X}_{2}$ terhadapVariabel $\mathrm{Y}$

\begin{tabular}{|r|c|}
\hline Model & $\mathbf{R}$ \\
\hline 1 & 0,656 \\
\hline
\end{tabular}

Sumber: Data Sekunder yang diolah, 2015

Berdasarkan Tabel 4.7 perhitungan di atas maka:

Koefisien korelasi antara perputaran modal kerja dan perputaran kas terhadap profitabilitas (ROA) sebesar 0,656. Ini berarti perputaran modal kerja dan perputaran kashampirtidakmempunyai pengaruh terhadap profitabilitas.

Tabel 4.8 Koefisien Determinasi $\left(\mathbf{R}^{2}\right)$

\begin{tabular}{|r|r|}
\hline Model & R Square \\
\hline 1 & 0,431 \\
\hline
\end{tabular}

Sumber: Data Sekunder yang diolah, 2015

Dari TabelKoefisien

0.431, hal ini berarti bahwa 43,1

Determinasi $\quad\left(\mathrm{R}^{2}\right) \quad$ dapat $\%$ profitabilitas

(ROA)

diketahui bahwa nilai $\mathrm{R}^{2}=$ 
signifikan yaitu perputaran

modal kerja dan perputaran

kas.Makadapatdikatakanjikanila

ikoefisiendeterminasitersebutsed

ang/cukupkarenaberadapada

$41 \%$ - $60 \%$. Sedangkan sisanya

$100 \%-43,1 \%=56,9 \%$

dipengaruhi oleh variabel yang lain.
Uji t

Apabila nilai $\mathrm{t}$ hitung < nilai t tabel, maka H0 diterima, sebaliknya apabila nilai t hitung $>$ nilai t tabel, maka $\mathrm{H} 0$ ditolak. Hasil pengujian hipotesis secara parsial dapat dilihat pada Tabel 4.9 berikut ini:

Tabel 4.9

Uji Partial

\begin{tabular}{|l|r|r|}
\hline \multicolumn{1}{|c|}{ Model 1 } & \multicolumn{1}{|c|}{ t } & \multicolumn{1}{c|}{ Sig } \\
\hline Konstanta & 1,224 & 0,223 \\
\hline Perputaran Modal Kerja $\left(\mathrm{X}_{1}\right)$ & 7,357 & 0 \\
\hline Perputaran Kas $\left(\mathrm{X}_{2}\right)$ & 4,604 & 0 \\
\hline
\end{tabular}

Sumber: Data sekunder diolah, 2015

Hasil analisis dengan

menggunakan bantuan program SPSS

Estatedan perusahaan manufaktur versi 19.0 diperoleh hasil sebagai berikut:

1) Pengaruh Perputaran Modal Kerja

Terhadap Profitabilitas (ROA)

Jadi nilai t hitung lebih besar

dari nilai $\mathrm{t}$ tabel $(7,357>1,978)$.

Artinya variabelperputaran modal kerja berpengaruh secara parsial terhadap profitabilitas (ROA).

Maka hasil penelitiandapat menerima hipotesis $\left(\mathrm{H}_{1}\right)$ pertama yang menyatakan "Perputaran modal kerja $\left(\mathrm{X}_{1}\right)$ berpengaruh terhadap profitabilitas (ROA) perusahaan Property and Real di BEI".

2) Pengaruh Perputaran Kas Terhadap Profitabilitas (ROA)

Nilai $\mathrm{t}$ hitung lebih besar dari nilai $t$ tabel $(4,604>1,978)$. Artinya variabel perputaran kas berpengaruh secara parsial terhadap profitabilitas (ROA) profitabilitas (ROA). Maka hasil penelitian dapat menerima hipotesis $\left(\mathrm{H}_{2}\right)$ kedua yang menyatakan "Perputaran kas $\left(\mathrm{X}_{2}\right)$ berpengaruh terhadap profitabilitas (ROA) perusahaan propertidan perusahaan manufaktur di BEI". 
Tabel 4.10

Uji Simultan

\begin{tabular}{|l|r|r|r|r|r|}
\hline \multicolumn{1}{|c|}{ Model } & Jumlah Kuadrat & Derajat Bebas & $\begin{array}{c}\text { Kuadrat } \\
\text { Tengah }\end{array}$ & $\begin{array}{c}\text { F } \\
\text { hitung }\end{array}$ & Sig \\
\hline Regression & 28234,156 & 2 & 14117,078 & 51,081 & $.000 \mathrm{a}$ \\
Residual & 37309,35 & 135 & 276,366 & & \\
\hline Total & 65543,506 & 137 & \multicolumn{3}{|c|}{} \\
\hline
\end{tabular}

Sumber: Data sekunder diolah, 2015

Nilai $\mathrm{F}$ hitung lebih besar dengan nilai $\mathrm{F}$ tabel $(51,081>3,06)$ dengan nilai probabilitas sebesar 0,000, karena nilai probabilitas lebih besar dari 0,05 maka $\mathrm{H}_{3}$ diterima dan menolak H0. Jadi dapat dikatakan bahwa Perputaran Modal kerja dan Perputaran kas secara simultan berpengaruh terhadap profitabilitas (ROA) (Y) perusahaan Property and Real Estate dan perusahaan manufaktur di BEI.

\section{Uji Beda}

1. Perputaran Modal Kerja

Tabel 4.13 Uji Beda Perputaran Modal Kerja

\begin{tabular}{|l|r|r|r|}
\hline & $\mathrm{t}_{\text {hitung }}$ & df & $\begin{array}{c}\text { Sig. (2- } \\
\text { tailed) }\end{array}$ \\
\cline { 2 - 4 } Perputaran Modal Kerja & 3,213 & 136 & 0,002 \\
\hline
\end{tabular}

Sumber: Data sekunder diolah, 2015

BerdasarkanTabel 4.13, diketahuijikanilait $_{\text {hitung }}$ variabelperpu taran modal kerjaadalah 3,213 $>t_{\text {tabel }}(1,978) \quad$ dengansignifikansi $0,002<$ alpha $(\alpha)$ 5\%.Iniberarti
$\mathrm{H}_{0}$ ditolakdan $\mathrm{H}_{1}$ diterima, artinyavariabelpopulasiperputaran modal kerjaantaraperusahaanmanufakturda npropertiadalahberbeda.

Tabel 4.14 PerbandinganPerputaran Modal Kerja Antar Perusahaan

\begin{tabular}{|c|l|l|}
\hline $\begin{array}{c}\text { Perputaran Modal } \\
\text { Kerja }\end{array}$ & $\begin{array}{l}\text { Perusahaan } \\
\text { Manufaktur }\end{array}$ & $\begin{array}{l}\text { Perusahaan } \\
\text { Properti }\end{array}$ \\
\hline
\end{tabular}




\begin{tabular}{|l|c|c|}
\hline Jumlah Perusahaan & 105 & 33 \\
\hline Rata-rata & 20.144920 & 6.542924 \\
\hline StandarDeviasi & 23.4054204 & 11.4720892 \\
\hline
\end{tabular}

Sumber: Data sekunder diolah, 2015

Perbedaan ini disebabkan

6.542924.Sehingga perputaran

nilai perputaran modal kerja modal kerja pada perusahaan perusahaan manufaktur memiliki manufaktur lebih baik dibandingkan rata-rata $\quad$ sebesar 20.144920 perusahaan properti.

sedangkan perusahaan property

2. PerputaranKas

memiliki rata-rata sebesar

Tabel 4.15Uji Beda PerputaranKas

\begin{tabular}{|l|l|l|l|}
\hline \multirow{2}{*}{ Perputaran Kas } & Thitung & df & $\begin{array}{l}\text { Sig. (2- } \\
\text { tailed) }\end{array}$ \\
\cline { 2 - 4 } & 4,654 & 136 & 0 \\
\hline
\end{tabular}

Sumber: Data sekunder diolah, 2015

BerdasarkanTabel $\quad 4.14$

$\mathrm{H}_{1}$ diterima,

diketahuijikanilait $_{\text {hitung variabelperpu }}$

artinyavariabelpopulasiperputaranka

tarankasadalah $4,654>\mathrm{t}_{\text {tabel }}(1,978)$ santaraperusahaanmanufakturdanpr

dengansignifikansi $0,000<$ alpha opertiadalahberbeda

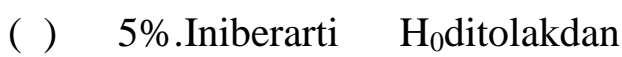

Tabel 4.16 PerbandinganPerputaranKas

Antar Perusahaan

\begin{tabular}{|l|c|c|}
\hline \multicolumn{1}{|c|}{ PerputaranKas } & $\begin{array}{l}\text { Perusahaan } \\
\text { Manufaktur }\end{array}$ & $\begin{array}{l}\text { Perusahaan } \\
\text { Properti }\end{array}$ \\
\hline Jumlah Perusahaan & 105 & 33 \\
\hline Rata-rata & 33.717649 & 10.487194 \\
\hline StandarDeviasi & 26.5812275 & 19.0375570 \\
\hline
\end{tabular}

Sumber: Data sekunder diolah, 2015
Perbedaan ini disebabkan
property memiliki rata-rata sebesar
nilai perputaran kas perusahaan 10.487194. sehingga perputaran kas manufaktur memiliki rata-rata pada perusahaan manufaktur lebih sebesar 33.717649 perusahaan 
baik dibandingkan perusahaan

3. Profitabilitas (ROA)

properti.

Tabel 4.17Uji Beda Profitabilitas (ROA)

\begin{tabular}{|l|l|l|l|}
\hline & Thitung & Df & $\begin{array}{l}\text { Sig. (2- } \\
\text { tailed) }\end{array}$ \\
\cline { 2 - 4 } Profitabilitas (ROA) & 2,808 & 136 & 0,006 \\
\hline
\end{tabular}

Sumber: Data sekunder diolah, 2015

BerdasarkanTabel 4.15,

5\%.Iniberarti $\mathrm{H}_{0}$ ditolakdan $\mathrm{H}_{1}$ diketahui jika nilai $t_{\text {hitung variable }}$ profitabilitas (ROA) adalah $2,808>t_{\text {tabel }} \quad(1,978) \quad$ dengan signifikansi $0,006<$ alpha $(\alpha)$ diterima, artinya variable populasi profitabilitas (ROA) antara perusahaan manufaktur dan properti

Tabel 4.18 PerbandinganProfitabilitas (ROA)

Antar Perusahaan

\begin{tabular}{|l|c|c|}
\hline \multicolumn{1}{|c|}{$\begin{array}{c}\text { Profitabilitas } \\
\text { (ROA) }\end{array}$} & $\begin{array}{c}\text { Perusahaan } \\
\text { Manufaktur }\end{array}$ & $\begin{array}{l}\text { Perusahaan } \\
\text { Properti }\end{array}$ \\
\hline Jumlah Perusahaan & 105 & 33 \\
\hline Rata-rata & 21.053273 & 9.092758 \\
\hline StandarDeviasi & 23.5103398 & 11.8150547 \\
\hline
\end{tabular}

Sumber: Data sekunder diolah, 2015

Perbedaan ini disebabkan

maka memperbesar pula niai nilai profitabilitas (ROA) profitabilitas perusahaan tersebut.

perusahaan manufaktur memiliki rata-rata sebesar KESIMPULAN

21.053273sedangkan perusahaan Berdasarkan analisis data profitabilitas rata-rata sebesar 9,092758 sehingga profitabilitas (ROA) berbanding lurus dengan laba sebelum pajak dan berbanding terbalik dengan total aktiva, dengan semakin besarnya nilai laba sebelum pajak pada perusahaan manufaktur yang telah dilakukan pada Bab IV maka dapat disimpulkan sebagai berikut :

1. Berdasarkan pengujian hipotesis 1 menunjukan bahwa perputaran modal kerja berpengaruh signifikan terhadap variabel profitabilitas (Return On Asset) sehingga hipotesisi 1 diterima 
perputaran modal kerja mempengaruhi ROA. Sehingga sesuai teorinya Kasmir (2013) seberapa banyak modal kerja berputar selama suatu periode atau dalam suatu periode. Perputaran modal kerja (working capital turn over) mempengaruhi salah satu rasio untuk mengukur atau menilai keefektifan modal kerja perusahaan selama periode terntentu.

2. Berdasarkan pengujian hipotesis 2 menunjukan bahwa perputaran kas berpengaruh signifikan terhadap variabel profitabilitas (Return On Asset) sehingga hipotesisi 2 diterima perputaran kas mempengaruhi ROA. Sehingga sesuai teorinya Kasmir (2013) semakin tinggi efesiensi penggunaan kasnya dan keuntungan yang di peroleh akan semakin tinggi pula keuntungannya.

3. Berdasarkan pengujian hipotesis 3 menunjukan bahwa perputaran modal kerja, perputaran kas berpengaruh terhadap variabel profitabilitas (Return On Asset) sehingga hipotesisi 3 diterima perputaran modal kerja dan perputaran kas mempengaruhi ROA.
4. Berdasarkan pengujian hipotesis 4 menunjukan bahwa terdapat perbedaan antara perputaran modal kerja, perputaran kas dan pfofitabilitas yang terdapat di perusahaan properti dan perusahaan manufaktur, sehingga perbedaan ini terbukti dengan adanya nilai jumlah antar perusahaan yang berbeda dan mempunyai nilai siginifikansi yang berbeda. Sehinga hipotesis 4 terdapat adanya perbedaan antara perputaran modal kerja, perputaran kas dan profitabilitas di perusahaan manufaktur dan perusahaan manufaktur selama tahun 2010,2011 dan 2012 yang terdaftar di BEI.

\section{SARAN}

a. Bagi investor dan calon investor perusahaan yang terdaftar di BEI agar lebih seksama dan juga memperhatikan aspek modal kerja dan juga tingkat nilai rasio terutama ROA (Return On Assets) perusahaan sebagai pertimbangan dalam melakukan investasi.

b. Pihak manajemen menentukan dan mengatur dalam menentukan modal kerjanya. Meskipun perputaran modal kerja dan perputaran kas berpengaruh simultan terhadap profitabilitas namun peran 
manajemen keuangan sangat

penting, karena penggunaan modal

kerja yang efektif dapat menentukan

besarnya profitabilitas yang didapat.

c. Bagi peneliti lain, hendaknya dalam melakukan penelitian menggunakan analisis rasio profitabilitas lain, sehingga dapat diketahui variabel mana yang lebih berpengaruh sebagai upaya meningkatkan profitabilitas.

d. Perluasan sampel dan menambah periode penelitian dengan menggunakan data time series periode yang lebih panjang dan dengan menggunakan data terbaru sehingga hasilnya akan lebih akurat.

\section{DAFTAR PUSTAKA}

Alok, Kumar, 2009, "Dynamic Style Preferences of Individual Investors and Stock Return,",Journal of Financial \& Quantitative Analysis

Astagfirli, Ratih Gayatri. 2012. Pengaruh perputaran modal kerja, perputaran total aset dan rasio utang terhadap rentabilitas pada perusahaan properti dan real estate yang terdaftar di BEI 2007-2011. Jurusan Akuntansi Fakultas Ekonomi Universitas Maritim Raja Ali Haji Tanjungpinang.

Azlina, Nur. 2009. Pengaruh Tingkat Perputaran Modal Kerja, Struktur ModalDan Skala Perusahaan Terhadap Profitabilitas. Dosen Fakultas Ekonomi Universitas Riau.
Brigham, Eugene F. (1983).

"F undamentals of $F$ inancial

Management". Third

Edition. Holt-Saunders Japan: The Dryden Press.Brigham, F, Eugene.

Budiasa, Trisna Herawati, Musmini. 2014. Pengaruh perputaran modal kerja terhadap rentabilitas ekonomi Pada perusahaan manufaktur yang terdaftar pada BEI 2010-2012. Jurusan Akuntansi Program S1 Universitas Pendidikan Ganesha Singaraja, Indonesia.

Christanti, Natalia dan Mahastanti, Linda Ariany (2011) Faktor-faktor Yang Dipertimbangkan Investor Dalam Melakukan Investasi. Jurnal teori dan terapan, Fakultas Ekonomika dan Bisnis Unversitas Kristen Satya Wacana, Salatiga.

Damodaran, Aswath. 1997. Corporate Finance Theory and Practice, Jhon \& Wiley and Sons. Inc. New York, Chichester, Toronato, Singapore Weinhein.

Deni, Irman. 2014. Pengaruh tingkat perputaran kas, perputaran piutang dan perputaran persediaan terhadap profitabilitas pada perusahaan manufaktur yang terdaftar di BEI. Program Studi Akuntansi, Fakultas Ekonomi, Universitas Maritim Raja Ali Haji (UMRAH), Jl.Politeknik Senggarang, Kepulauan Riau, Indonesia.

Fahmi, I. 2012. Analisis Laporan Keuangan. Bandung: Alfabeta.

Ferdinand, A. T. 2006. Metode Penelitian Manajemen, BP Undip, Semarang.

Firdaus A. Dunia. 2008) Manajemen Persediaan, Ed 2, Pt. Raja Gafindo Persada, Jakarta. 
F. Bringham, Eugene dan Joel F. Houston. 2004. Dasar-Dasar Manajemen Keuangan, Ed 10, Alih Bahasa: Ali Akbar Yulianto, Salemba Empat, Jakarta.

Hanafi, 2014. Efesiensi Modal kerja, likuiditas dan levetage terhadap profitabilitas pada perusahaan di BEI. Fakultas Ekonomi, Universitas Negeri Semarang, Indonesia.

Halim Abdul, 2005, Analisis Investasi, Edisi 2, Salemba empat, Jakarta.

Husnan, S dan Pujiastuti, E. 2002. DasarDasar Manajemen Keuangan. Yogyakarta: Akademi Manajemen Perusahaan YKPN.

Houston, F, Joel. 2001. Manajemen Keuangan. Jakarta: Erlangga.

Kasmir. 2013. Analisis Laporan Keuangan. Jakarta: PT RAJAGRAPINDO PERSADA.

Keown et al. 2010. Financial Management: Principles and Application. Terjemahan Marcus Prihminto Widodo, M.A. Edisi kesepuluh. Pt. Indeks.

Komaruddin, 2005. Dasar-Dasar Manajemen Investasi Dan Portofolio, ed.2, Rineka Cipta, Jakarta.

Kuncoro, Mudrajat, (2001), Metode Penelitian Kuantitatif, UPP AMP YKPM, Yogyakarta

Kusumaningrum, Dyah, 2012. PengaruhKeputusanInvestasi,

KeputusanPendanaan,

KebijakanDeviden,

KepemilikanManajerialdanKepemilik anInstitusionalTerhadapNilai

Perusahaan (study Empirispada Perusahaan yang terdaftar di BEI 2011-2012)
MahasiswafakultasekonomiAkuntansi Universitasdiponegorosemarang 20913.

K.R, S. \& Wild, J. J. 2010. Analisis Laporan Keuangan. Jakarta: Salemba Empat.

Makowitz. M. 1927. Economic Nobel Prize University Chicago.

Mamduh M Hanafi Dan Abdul Halim. 2007. Analisis Laporan Keuangan, Ed Ketiga, Cetakan Pertama, Upp Stim Ykpn, Yogyakarta.

Mariah,

2012.

PengaruhProfitabilitasdanKesempata nInvestasiTerhadapKebijakanDividen TunaiDenganLikuiditasSebagaiVaria bel Moderating padaEmitenPembentukIndeks LQ 45 (Periode 2008-2010). Mahasiswi FakultasEkonomi, Program Studi Akuntansi Universitas Kristen Maranatha.

Mulyono ,Teguh Pudjo. 2000. Analisa Laporan Keuangan Untuk Perbankan. Edisi Revisi. Jakarta: Djambatan

Munawir, S, 2004. Analisis Laporan Keuangan. Liberty. Yogyakarta.

Munawir, S. 2007. Analisa Laporan Keuangan. Edisi keempat, cetakan keempat belas. Yogyakarta: Liberty

M. Fuad, Christin H, Nurlaela, Paulus. 2000. "Pengantar Bisnis". Jakarta:Gramedia.

Nagy Robert A. dan Obenberger Robert W, 1994, "Factors Influencing Individual Investor

Nazir.M , (2005), Metode Penelitian, Cet

Kelima, Ghalia Indonesia, Jakarta.

Noratika, Dewi 2014. Pengaruh Perputaran Modal Kerja, Perputaran Piutang, 
Terhadap Net Profit Margin Pada Perusahaan Industri Barang Konsumsi Yang Terdaftar Di BEI Periode 2009-2013.

Pustpitaningtyas, Zarah

Pembentukan Model Prediksi Risiko Investasi Saham Berdasarkan Decision Usefulness Approah Of Accounting Information, seminar Nasional \&Call for Paper 2011: Kajian Penelitian Aktual Guna Pengembangan Teori Baru Bidang Ekonomi \& Bisnis. Sidoarjo: Fakultas Ekonomi Universitas Muhammadiyah Sidoarjo.

Prakoso,Zahroh Z.A, Nuzula, 2014. Pengaruh Perputaran Modal Kerja dan Perpitaran Piutang Terhadap Profitabilitas (Studi Pada Perusahaan Pembiayaan Listing di BEI Periode 2009-2013). Fakultas Ilmu Administrasi Bisnis Univesitas Brawijaya Malang.

Pratiwi, Ratih. 2012. Pengaruh Perputaran Mdal Kerja terhadap Return On Asset (ROA) Perusahaan (Studi Kasus Pasa Toko Global Computer Periode 20062010). Skripsi Manajemen Universitas Pasundan Bandung.

Qawi, Raluca B. (2010) Behavior Finance: Is Inventor Psyche Driving Market Perfomence IUP Jurnal Of Behavioral Finance. Vol. 7, No.4.

Rahadjeng, Erna R. (2011) Analisi Perilaku Investor Perspektif Gender Dalam Pengambilan Keputusan Investasi Di Pasar Modal. Humanity, Vol. 6, No. 2.

Rejesh, M dan N.R.V. Ramana Reddy. 2011. Impact of Working Capital Managemen on Firm's Profitability. Global Journal of Finance and Management. 3 (1).PP.279-300. R. Agus Sartono, (2001), Manajemen
Keuangan Teori dan Aplikasi, Ed Keempat, Cet Ketujuh, BPEF, Yogyakarta.

Riduwan, 2010. Skala pengukuran variabelvariabel penelitian, Alfabeta, bandung.

Riyanto, 2008. Dasar-Dasar Pembelanjaan Perusahaan, Ed Keempat, Cetakan Kedelapan, Bpfe, Yogyakarta.

Rudianto, 2009. Pengantar Akuntansi. Jakarta: Erlangga.

Santoso, 2001. Mengolah data statistik secara profesional. Jakarta. Alex Media Kompotindo.

Sartono R. Agus, 2001. Manajemen Keuangan Teori dan Aplikasi, Ed Keempat, Cet Ketujuh, BPEF, Yogyakarta.

Syafri, Harahap Syofyan, 1999. Analisa Kritis Atas Laporan Keuangan. Edisi Pertama. PT. Raja Grafindo Persada. Jakarta.

Singh, Ranjit (2009) Behavioural FinanceThe Basic Foundations. ASBM Journal OfManagement.

Sitorus, Irsutami, 2012. Analisis Pengaruh Manajemen Modal Kerja Terhadap Profitabilitas (Studi Kasus Pada Perusahaan Properti dan Real Estate yang Go Public di BEI Tahun 2006 2011). Politeknik Negeri Batam Jl Parkway Batam Centre, Batam 29461, Indonesia.

Sugiono, Arif dan Untung, Edi. 2008. Panduan Praktis Dasar Analisa Laporan Keuangan. Jakarta: Grasindo.

Sugiyono, 2006, Metode Penelitian Bisnis, CV. Alfabeta, Bandung.

Sundjaja, Ridwan. S dan Barlian, Inge, 2003. Manajemen Keuangan 1, Edisi Kelima. Literata Lintas Dunia, Jakarta. 
Sukirno, 1997. Pembelajaran Perusahaan (Dasar-Dasar Manajemen Keuangan). Edisi Ketiga. Liberty, Yogyakarta

Sukirno, Sadono. 2005. Mikro Ekonomi Teori Pengantar, Edisi Ketiga. Jakarta : PT Raja Grafindo Persaja.

Syamsuddin, Lukman, 2001. Manajemen Keuangan Perusahaan. PT. Raja Grafindo Persada, Jakarta.

Soemarso, S.R. 1996. Akuntansi Suatu Pengantar, edisi 4. Jakarta: Rineka Cipta.

S. Munawir, (2004), Analisa Laporan Keuangan, Ed Keempat, Cetakan Keempat belas, Liberty, Yogyakarta.

Taffler, Ghazali (2009) Hubungan Perilaku Perdagangan Investor Dengan Volume Perdagangan Di Bursa Efek Indonesia Jurnal Manajemen Teori dan Terapan.

Toral Al, 2002, 'Other Ways to Score Invesment Points", Pure Fundamentalist

Wahyuni,Ekasri, 2013, "Pengaruh Profitabilitas, Likuiditas, Dan Ukuran Perusahaan Pt Sepatu Bata Tbk", Skripsi, Universitas Pendidikan Indonesia (Repository.Upi.Edu Diakses 6 November 2014 pukul $19.00 \mathrm{wib})$.

Werren, Carl S, James M Reeve dan Philip E Fess, 2006. Pengantar Akuntansi , Jakarta: Penerbit Salemba Empat.

Weston, J. Fred dan Eugene F. Brigham, 1999. Dasar-dasar Manajemen Keuangan. Diterjemahkan oleh A. Q Khalid. Erlangga, Jakarta.Kasmir. 2013. "Analisis Laporan Keuangan". Edis 1. Cetakan ke-6. Jakarta: Rajawali Pers. 